\title{
Sustainable Management of Water Resources in Urban Areas
}

\author{
Drenushe Fidani* and Violeta Gesovska \\ Department of Civil Engineering, University Ss. Cyril and Methodius, North Macedonia
}

Submission: July 11, 2019; Published: August 05, 2019

*Corresponding author: Drenushe Fidani, Department of Civil Engineering, University Ss. Cyril and Methodius, North Macedonia

\begin{abstract}
Water is the basis for survival of the mankind, but its spatial and temporal distribution is extremely uneven. In their activities, people use water, affecting at the same time the natural balance, inflicting thus major consequences for the human, the overall living and plant environment. This paper is aimed at illustrating some of the challenges faced by competent policy makers and planners in managing water resources for the purpose of implementation of the sustainable development goal related to water management and sanitation. Through specific problems in the territory of the R. of North Macedonia, a comparative analysis of sustainable development goals and experience in urban areas, specifically in the city of Gostivar, is made. It is concluded that steps have certainly been taken for the last three years, but a lot has still to be done regarding observation of legal obligations in the sphere of sustainable management of water resources in urban areas.
\end{abstract}

Keywords: Sustainable development; Water resources management; Urban area

\section{Introduction}

Water is essential for life on the Earth and its role in city planning is fundamental. There is no life without water, but the growing challenges in the form of urbanization, economic growth, pollution and climate changes are disturbing the stability of the water flow cycle and the maintenance of the environment by exerting pressure on water resource management.

Water should not be treated as an isolated element because it is an inseparable part of a city design. In urban areas, it integrates several interrelated fields such as protection against climate changes, quality of life, resources, etc. All these relations explain the importance of water in sustainable urban development [1]. As a result, physical planning of the city and management of water resources must be done in parallel.

Cities are the main problem makers during sustainable water management solution choosing, but at the same time, they might be problem solvers, as well. "For a society to be sustainable, economic, environmental and social factors must all be in balance" [2]. The balance breaks down when human needs exceed the natural proportions. From the aspect of water, as a key element of development, this happens as a result of poor water management, lack of adaptation of current technologies, improper functioning of relevant institutions and lack of response in times of crisis. Inadequate water resource management is reflected through water quality, including pollution of surface waters, and water quantity, involving two extremes, floods and droughts, both of which are the major features of the urban civilization [3]. This is because, in many cases of urbanization, water resource management takes place at a later phase [4], through inappropriate coordination and local management as the city expands.

We are witnesses of enormously rapid development of cities and urbanization that are sometimes without proper analysis of their impact on the natural environment and the overall space, in general. In such conditions, when larger areas are urbanized and turned into urban areas with residential buildings and asphalted or paved surfaces, the amount of water that comes from the atmosphere as a surface runoff increases. This increase is due to an increase in the leakage ratio, which is in direct correlation with the land use pattern. It is very small in the case of natural surfaces (0.15-0.35) and higher in the case of artificial surfaces (0.90-0.95-asphalted surfaces and roof surfaces) [5]. As a result, the flood waves from precipitation that occur in urban areas are several times larger and with a very short time of concentration.

In circumstances where urbanization of areas is done without parallel increase of the capacity of water infrastructure facilities (river regulation, water supply system and sewerage systems, drainage and irrigation systems), urban areas face frequent river floods. These problems combined with the global climate change 
manifested by extremely highly intensive rainfalls are nowadays major ones not only in our country, but also globally. Therefore, the main purpose of this research paper is to illustrate some of the challenges faced by competent policy makers and planners in managing water resources. The purpose has been to explore the level of implementation of the sustainability goals regarding management of water resources in the city of Gostivar, as a case study, by analyzing the use of water in the urban part of the city from all aspects: potable water, water supply system, waste water, flood protection system and irrigation system.

\section{Sustainable Development}

"Sustainable development is development that meets the needs of the current generation without compromising the opportunities of future generations to meet their needs", [6].
United Nations General Assembly adopted the Sustainable Development Goals as an integral part of the 2030 Agenda for Sustainable Development [7]. They explained the concept of sustainable development in more details, identifying the specific target for each goal and the implementation frame of these goals [8].

The total number of Sustainable Development Goals (SDGs) is 17 [7], as shown in Figure 1. Each of these has its own importance in the sustainable development, including availability and sustainable management of water and sanitation, which is the central topic of this research article. The sixth goal - to ensure availability and sustainable management of water and sanitation for all, is closely linked to the goals related to infrastructure, cities and human settlements as well as climate change.

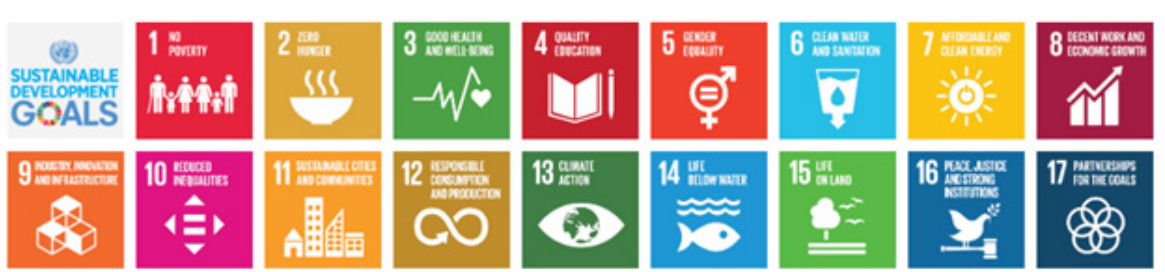

Figure 1: Sustainability Development Goals. (Source: Sustainabledevelopment.un.org). Sustainable Development Knowledge Platform.

Confronted with the challenges of the new time, not only science but also societies are becoming aware that sustainable development is not possible without sustainable management of water resources, [9]. Until recently, management of water resources was the task and responsibility of water engineers only. However, since water is a common good, it is everyone's responsibility to take care of it. For many years, people involved in management of water recourses have been using various techniques to serve human beings, including building of infrastructures, regulation of river flows for flood control, building of power plants, but now it is time for establishing new criteria that will enable sustainable management of water resources, [10].

\section{Sustainable Development and Water}

Sustainable development is a collection of principles and advices whose pursuit will enable a better economic, social and ecological life. Since water is the keystone of life, sustainable development cannot be successful without sustainable management of water resources. For this purpose, many different methods and technologies can be applied.

The sixth goal, from the 17 Sustainability Development Goals is the goal of ensuring availability of water and sanitation for all by 2030 [7]. This goal is closely linked to other goals playing an essential role in human life. If properly implemented, they guarantee access to safe and affordable drinking water, sanitation and hygiene for all, improved water quality, substantially increased water-use efficiency, integrated water resource management at all levels and protection of water- related ecosystems. The progress of goal 6 within a period of three years has resulted in safely treated 59 percent of all domestic wastewater. In 22 countries, the water stress level is above 70 percent, indicating a strong probability of future water scarcity. 157 countries reported average implementation of integrated water resource management of 48 percent. Still, too many people are lacking access to safe drinking water and sanitation facilities [7].

Sustainable water resource management in urban areas within the European Union (EU) was established by the strategic framework known as The European Water Framework Directive (WFD), which was entered into force in 2000. "The WFD provides a framework for water protection and management in the EU" [11]. This framework includes programs for river basin management plans in each European country in order to improve and protect environment and raise the quality of life. EU member states must communicate and corporate to achieve the goal of sustainable water management [12] taking advantage of time and taking one another as an example. The following elements of the European Water Policy came up with the WFD: protection of all waters, surface waters, and groundwater; river basin management; good status of all waters by a set deadline; getting the prices right; public participation; coordination of measures [13]. In addition, over time, four other directives have been added to these directives to "ensure the good status of Europe's waters": the Urban Waste Water Directive, the Bathing Water Directive, the Nitrates Directive, the Drinking Water Directive, The Floods Directive [11]. 
Before even setting the goals of SD, Palme, [14], has made a deep study for application of sustainable development indicators in managing water resources in Sweden. For the purpose of identification of the drivers and the barriers in application of the sustainable development indicators in sustainable water management, 47 key actors have been interviewed, including organizational inertia, social capital, the national water sector and the authorities in three different municipalities. It has been concluded that the common characteristics of these drivers and barriers are: the attitude to Sustainable Development Indicators policy, trust and clear communications. This theory confirms that the drivers are the water sector and the authorities [14].

A study made in Bangladesh regarding the seven key dimensions of the Integrated Water Resource Management (IWRM) shows the status of IWRM. Being one of the developing countries, Bangladesh is facing many water resource management challenges. After the analysis made "through the lens of policy shifts, institutional transitions and project transformations" it has been deduced that Bangladesh has made progress toward achieving the sustainable goal for water and that the principles of IWRM are well reflected in the policy of the country. It has also been concluded that "multi-sector, multi-agency, participatory and collaborative approaches" are necessary to manage water resources according to the Sustainable Development Goal. To achieve the goal, more developed counties should be taken as examples, [15].

Another approach to sustainable water resource management has been made through the ecological waste water management systems such as the "closed-loop systems" [16]. These systems include biodegradation of organic wastes into valuable products by using the natural reaction of plants, microorganisms and sunlight. In addition, some innovative sanitation technologies such as solar septic tanks and hydrothermal carboniาzation of fecal sludge have been helpful to fulfill the closed-loop systems "because they effectively inactivate the pathogens, remove the pollutants and produce valuable by-products such as biogas and hydrochar" [16]. As a result, these technologies can be a framework for sustainable water resource management. At the same time, common barriers such as "policies, regula 7 tory procedures and budget planning" must be taken into consideration. One of the well-known techniques for sustainable water resource management is managed aquifer recharge (MAR). MAR can be used for many water sources such as: mains water, rain water, storm water, reclaimed water, rural runoff in combination with other sustainable water resource management: "wastewater recycling, storm water harvesting, saline groundwater intrusion and flood management and mitigation". Once again it has been concluded that without "urban water resource management policy development, transparent reporting of costs, and improved institutional coordination" the achievement of the full potential role of MAR in delivering sustainable urban water management is impossible [17].
A technique that is easy to be implemented is the collection of rainwater [18] before it reaches the ground in order to provide more clean water and protect an urban area from flooding. "More land can be used for buil-ding high-rise apartment blocks - on the condition that flooding is reduced to a minimum by rainwater collec-tion and management" [4]. This can be achieved through legislation on construction of retention basins (spaces for storage of atmospheric water that improve the quality of water by natural processes such as soil filtration) for each newly built structure and conversion of the land from agricultural/natural to urban environment (asphalted roads, roof surfaces) where the leakage ratio is several times greater than that of the natural environment.

Considering scientific researches, many approaches have been invented to enable sustainable water resource management even though all of them need the support of the authorities. The very first thing that needs to be done in such approaches is to measure the attitude of the authorities toward sustainable water resource management, involving decision makers, the water management sector, planners and communities.

\section{Implementation of Sustainable Management of Water Resources in R. of N. Macedonia}

In the subsequent text, activities and measures taken for sustainable development of water resources in an urban area in R. of N. Macedonia are analyzed by taking as an example the city of Gostivar. Problems and possible solutions are also elaborated.

In the Republic of Macedonia, the Law on Waters (2013) [19] guarantees a framework for protection and sustainable management of water resources. The responsibilities, obligations and competences rest with six ministries, namely, the Ministry of Environment and Physical Planning, the Ministry of Transport and Communications, the Ministry of Agriculture, Forestry and Water Economy, the Ministry of Economy, the Ministry of Education and Science, the Ministry of Health and the Republic Institute for Health Protection [19].

The main strategic documents for SDG 6 that govern and address all the goal's targets are the National Water Strategy of RM (2012), the Master Plan for Water (unfinished) and River Basin Management Plans (only some of these plans have been prepared) [20].

After the analysis of the implementation of policies for accomplishment of the goal's targets in the R. of N. Macedonia has been made, it has been concluded that the targets of goal 6 presently represent a challenge for the country. Although formulated strategies and priorities that match SDG 6 exist, they do not guarantee progress toward the achievement of certain targets, [21].

Evaluation of the progress in the field of water is also given in the EU Country Progress Report for Macedonia (2018) which states that specific implementation plans for the Urban Waste 
Water Treatment and Drinking Water Directives have been developed; a national investment program for the water sector has been developed; the river basin management boards are still under preparation; the new pricing methodology, based on full cost recovery, is being applied in municipalities with over 10 000 people. More efforts are required: to reduce non-revenue water; in enforcement and inter-institutional coordination; for alignment with the Nitrates and Bathing Directives while the Groundwater and Water Quality Standards Directives remain at an early stage of transposition [11]. Most of the strategies for implementation of goal 6 of the SDGs in Macedonia are also conditions for R. N. Macedonia to access EU.

\section{Case Study - the City of Gostivar}

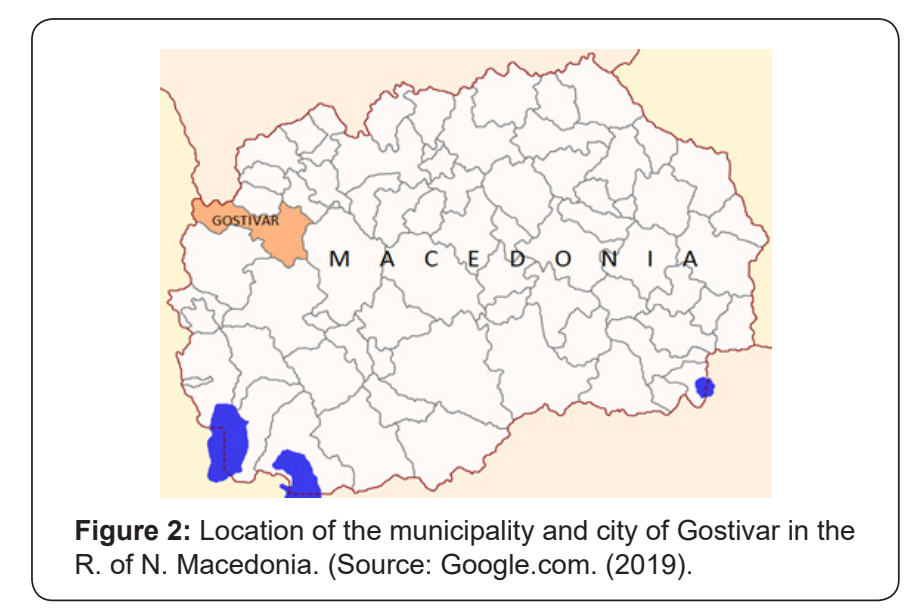

Gostivar is a city in the western part of the Republic of North Macedonia, Figure 2. It is part of the Polog statistical region. It is the city where Vardar, the greatest river in Macedonia begins to flow. Vardar River runs through Gostivar, dividing it into halves, passes through the capital Skopje, stretches through the country, enters Greece and finally reaches the Aegean Sea.

The management of the water resources in the town of Gostivar is done by two main institutions that work on water management in the city including its surroundings. One is the Water Economy, a self-governing institution whose duty is primarily to supervise the Vardar river and the irrigation system, and the Public Utility Company "JPKD Komunalec", which is responsible for water supply and regulation of fecal and atmospheric sewerage.

The subsequent section shows analysis of the level of implementation of sustainable water resource management, considering the use of water in the urban part of the city of Gostivar from all aspects.

\section{Water supply system}

Many parts of the city of Gostivar suffer lack of water, mainly drinking water, especially during the summer months. Within the framework of the Municipality of Gostivar, there operates the Public Utility Company JPKD Komunalec, which is responsible for water supply. The system is even less developed in the surroundings of the city. The population is forced to be supplied with drinking water from the nearest possible water source or to drill their own wells. To fulfill this gap, the municipality of Gostivar has elaborated a huge project for the year 2019. It includes water supply for many parts of the city and its surroundings. An innovation in water management which has not been seen in this city before is the construction of 4 reservoirs at different points in the city. These reservoirs are planned to serve the community for at least three days in case of lack of water. The same water supply system that provides drinking water also supplies technical water for sanitation and hygiene.

Testing of the quality of water in the water supply system is done once a month. On the basis of the results from the conducted test and expert analysis by the Public Health Center in Tetovo, where the test was done in November 2018, it was concluded that the tested sample of drinking water is appropriate for use according to the regulations on drinking water safety [22].

The water supply system provides 900 to $1200 \mathrm{l} / \mathrm{s}$ for the citizens of Gostivar. Many parts of the city are without enough drinking water during the summer months, as a result of its misuse. There are individuals who use drinking water from the water supply system to irrigate their gardens regardless the water shortages.

\section{Waste water}

Urban waste water represents a significant pollution load. Where sanitation facilities are inadequate, all available channels become means for waste water disposal. The regulation of fecal and atmospheric sewerage in Gostivar is in charge of the Public Utility Company JPKD Komunalec. Considering that inadequate waste water treatment is a major risk for human health, it can be said that the waste water management in Gostivar is not at the appropriate level. The system for collection of fecal and atmospheric waters is not developed in the whole city. Some private settlements are solving this problem by opening septic tanks, but many of them don't have a solution. Consequently, fecal sewerage is polluting the streams and the Vardar river.

\section{Flood Protection System}

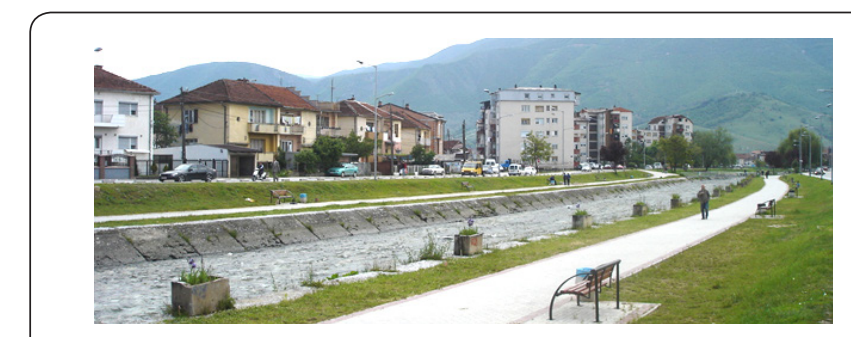

Figure 3: The Vardar river running through the urban area of the city of Gostivar. (Source: Google.com. (2019).

The flood protection system for the city of Gostivar involved regulation of the Vardar river bed in the urban area. The Vardar 
river bed running through Gostivar is regulated by a double trapezoid profile whose capacity is $46 \mathrm{~m} 3 / \mathrm{s}$ for a minor channel and $135 \mathrm{~m} 3 / \mathrm{s}$ for a major channel (Figure 3). With the regulated river bed, the urban area will be protected against flooding in the event of occurrence of these quantities of water [23].

\section{Irrigation system}

The main duty of the Water Economy sector, in addition to permanent maintenance of the Vardar corridor for the purpose of protection against floods, is the construction of new and reconstruction/rehabilitation of existing channels for irrigation. Currently, two projects are being implemented: the construction of a new channel from Raven, village near Gostivar, to the village of Rechitsa near Tetovo, and rehabilitation of the existing channel for irrigation of agricultural land starting in Zdunje village near Gostivar and running up to Pirok, Tetovo.

The Gostivar field irrigation system was built in the period $1964 / 1968$ as an open channel and open network for irrigation with furrows. It was reconstructed once in the period 1984/86, [24]. The basic elements of the irrigation system of Gostivar field are: the intake at Vardar river, the main channel Zdunje - Pirok with a length of $14.9 \mathrm{~km}$ and the irrigation network for $4300 \mathrm{ha}$. Reconstruction of this system began in 2017 and was finished recently by construction of an additional channel, namely the Raven-Rechitsa channel.

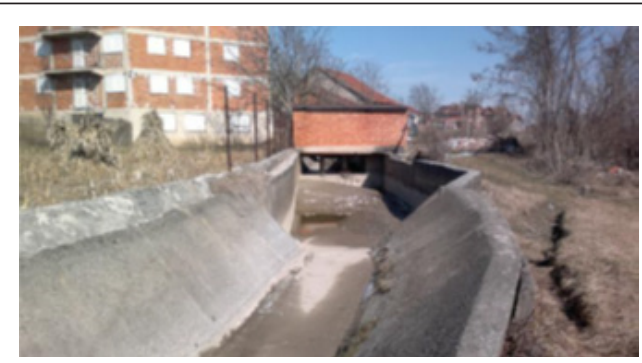

Figure 4: Current state of Zdunje-Pirok channel- urban area. (Source: [24]).

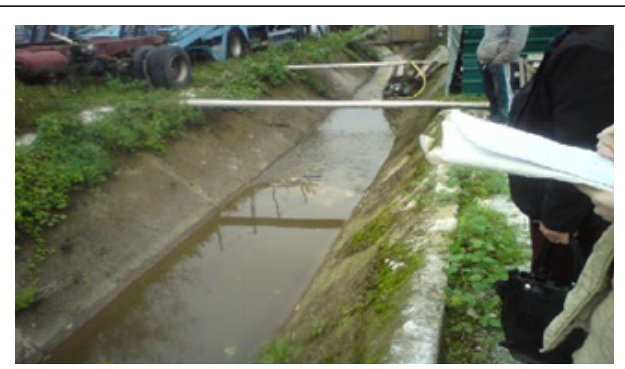

Figure 5: Current state of Zdunje- Pirok channel- out-of-town section. (Source: [24]).

In general, Zdunje - Pirok channel consists of two sections: the section passing through the urban area, namely through a settlement, Figure 4, and a section beyond the town area, Figure 5. Beside the channel passing through the urban part, a large number of residential buildings and individual houses were built and the fecal sewerage from these surrounding residential (individual) buildings used to be thrown directly into the channel so that it was converted into a main collector of sewerage waters.

Also, most of the solid waste was thrown in the channel by the community. In some parts of the channel, the owners of houses used to make passages over the open channel in order to enter individual houses. This open channel posed a great danger for the lives of the people for which there witnessed a lot of injuries. Taking all this into consideration, the reconstruction of the channel was done such that the part of the open channel that passes through the urban area was converted into a closed channel, while the section beyond the town remained open as shown in Figure 6 [24].

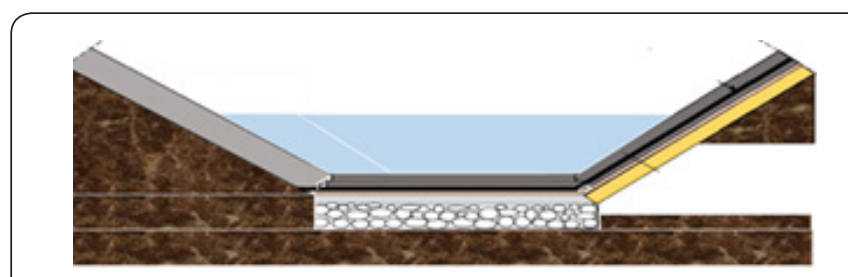

Figure 6: Plan of the Zdunje- Rechitsa channel. (Source: [24]).

The Raven-Rechitsa channel, Figure 9, is part of the program of the Ministry of Agriculture, Forestry \& Water Economy of the Republic of N. Macedonia. The purpose of this channel is to irrigate agricultural fields with reservoir water covering a territory of 3920 hectares situated on the right-upper side of the Tetovo-Gostivar highway down to the foothills of the Shar mountain, [25]. After the project passed all institutional filters, there started the field work, as shown in Figure 7.

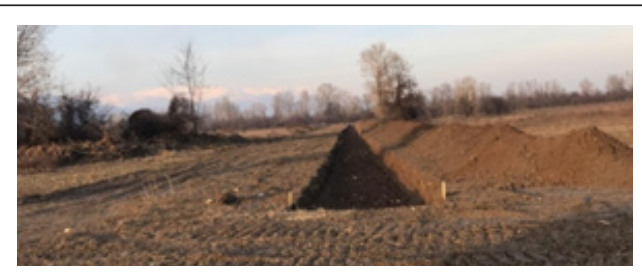

Figure 7: Current state of part of the Raven- Rechitsa channelagricultural land in Dobridol village. Source: self-research.

\section{Discussion}

As in many other urban areas, water management in the city of Gostivar faces many challenges, too. Furthermore, the lack of public awareness is also present. Hence, it is expected that the implementation of the last target of the SD Goal 6, Supporting and strengthening the participation of local communities in improving water and sanitation management will raise the awareness about water management.

It is unfortunate to have no proper flood, water supply and waste water treatment system in urban areas. For many years Gostivar has been dealing with this problem, so a great number of future projects related to water resources have been promised to be realized by the local authorities.

One group of projects is related to waste water treatment. 
Waste water becomes seriously dangerous for the health of citizens, especially when mixed with untreated industrial waste. Therefore, serious and urgent steps are expected to be taken by the authorities to this end.

The Vardar river bed, namely, the section passing through the urban area has been regulated for the purpose of protection against floods. It represents a positive step to sustainable development, but the regulation should be maintained continuously and the need for its reconstruction should be explored.

There are no major problems with irrigation system exploitation. In this area of water management, everyone is putting much efforts, both the authorities and the owners of the agricultural land who let part of their land to be used for these types of canals, for the common good, without asking for any compensation. Considering simultaneously the targets of goal 6 from the SDGs and the progress of the city of Gostivar, the city is obviously making progress toward the implementation of these targets of sustainable water resource management.

In addition to the stated above, it can be noted that, first of all, an analysis of the current situation is required. Based on detailed analyses, problems and sources of the problems should be detected. Without identifying the current situation, we will not be able to take the right steps toward sustainable development. In addition, an appropriate action should be taken to protect the city area from the floods, as well as actions to reduce flood waves by activities in the catchment area. Water resource management should start from the roots of the city, parallel to its physical planning. Also, an operational water management plan for the city of Gostivar should be made in the phase of designing of all water related facilities in the urban areas as well as in the wider area throughout the catchment area. This is necessary in order to mitigate or reduce damages due to the newly emerging conditions in the urban areas, such as river spillover, flooding of agricultural land combined with global climate change, etc.

All goals of sustainable development are in line with the human requirements for existence and wellbeing on the Earth. Water as an essential element of existence is present in all goals and is closely connected to each of them. Treating water in the city of Gostivar in the right way will not only make life easier but will also eliminate several problems that affect and complicate the proper development of the city and the wider area. As a result of this proper water management, the major part of Goal 6 is expected to be implemented.

\section{Conclusions}

Lack of proper water resource management is still present in the R. of N. Macedonia, causing flooding or scarcity of water. Even though much progress has been made toward sustainable water resource management, more action is still required because of various challenges.
Strategies for the implementation of Goal 6 of SDGs in the R. of Macedonia exist at least in relevant documents, but most of them are also conditions for the R. of N. Macedonia to join EU. To implement all the goals of SDGs, a country must have a clear and correct communication among the corresponding sectors, a positive attitude of the government toward sustainable development and a high awareness of the citizens. Since all the above mentioned is unfortunately not characteristic for the Republic of N. Macedonia, the implementation of the SDGs, specifically the targets of the goal 6 is well addressed, but there are gaps which need to be filled.

The next step would be to put into practice all the issues that are still standing in the papers only. Finally, it can be noted that many approaches can be used to provide a sustainable water resource management by using different methods and techniques even though all of them need the support of the authorities. City planners, water experts and organizations should cooperate among each other and should take timely and coordinated actions toward full implementation of the recommendations discussed in this paper.

\section{References}

1. Milosevic D, Winker M (2018) The role of water for sustainable urban planning - Dialogues of sustainable urbanisation: Social science research and transitions to urban contexts.

2. McManners P (2008) Adapt and Thrive. Oxford: Susta.

3. Schüler A, Haupter B (2010) Sustainable Development of Water Management in Urban Space.

4. Forssberg B, Malmqvist P, Sörelius H (2014) Process of Change: Successful Implementation of Good Water Management Practices in Six Cities.

5. Popovska C, Geshovka V (2012) Hydrology. Skopje: Faculty of Civil Engineering.

6. Kate RW, Parris TM, Leiserowitz AA (2005) What is Sustainable Development Goals, Indicators, Values, and Practice. Science and Policy for Sustainable Development, Issue of Environment 47(3): 8-21.

7. (2018) Transforming our world: the 2030 Agenda for Sustainable Development: Sustainable Development Knowledge Platform.

8. Kanie N, Biermann F (2017) Governing through goals. The MIT Press, USA.

9. Popovska C (2012) Eco-hydrology - a New Paradigm in Management and Restoration of Water Resources. Skopje: Faculty of Civil Engineering.

10. Theodore Heintz JH (2019) Applying the Concept of Sustainability to Water Resources Management. Universities Council on Water Resources, (127): 6-10.

11. (2018) Sustainable Water Management.

12. Jekel H (2005) Sustainable Water Management in Europe - the Water Framework Directive. NATO Science Series, pp. 121-127.

13. Pahl-Wostl C, Mostert E, Tàbara D (2008) The Growing Importance of Social Learning in Water Resources Management and Sustainability Science. Ecology and Society 13(1): 1-4.

14. Palme U (2010) On Prerequisites for the Application of Sustainable Development Indicators in Urban Water Management. Sustainability 2(1): 92-116. 
15. Gain A, Mondal M, Rahman R (2017) From Flood Control to Water Management: A Journey of Bangladesh towards Integrated Water Resources Management. Water 9(1): 55.

16. Polprasert C, Pussayanavin T, Kottatep T (2015) Urban Development and Water Sustainability.

17. Page D, BekeleE, Vanderzalm J, SidhuJ (2018) Managed Aquifer Recharge (MAR) in Sustainable Urban Water Management. Water 10(3): 239.

18. Bunpar (2013) 15 Ways to reduce your water consumption. In: Kindle (Ed.), ( $1^{\text {st }}$ ed), pp. 80-137.

19. (2010) Water Strategy for the Republic of Macedonia.

20. Dragovic N, Ristic R, Wolfschner B (2018) Natural Resources Management in SEE: Forests, Soils and Waters (Үправување со природни ресурси во ЈИЕ: шуми, почви и води).

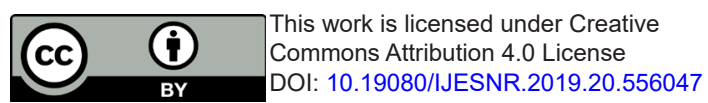

21. Natasha M (2016) Rapid integrated assessment and gap analysis, Development of National SDGs Implementation Plan 2016-2030 and SDGs Action Plan 2016-2020.

22. Berun M (2018) Public Health Center. Tetovo.

23. Elem (2016) Elaborate for Determining the Capacity of the Vardar River Bed Along the Section between Raven and the Railway Bridge in Gostivar.

24. Resurs (2017) Main Project for Rehabilitation of the Irrigation System.

25. (2018) Water Management Polog - Gostivar.

Your next submission with Juniper Publishers will reach you the below assets

- Quality Editorial service

- Swift Peer Review

- Reprints availability

- E-prints Service

- Manuscript Podcast for convenient understanding

- Global attainment for your research

- Manuscript accessibility in different formats ( Pdf, E-pub, Full Text, Audio)

- Unceasing customer service

Track the below URL for one-step submission https://juniperpublishers.com/online-submission.php 